\title{
Neuroprotective Factors of the Retina and Their Role in Promoting Survival of Retinal Ganglion Cells: A Review
}

\author{
Ewa Fudalej $^{\mathrm{a}}$ Magdalena Justyniarska ${ }^{\mathrm{a}}$ Kaja Kasarełło ${ }^{\mathrm{a}} \quad$ Jacek Dziedziak $^{\mathrm{a}, \mathrm{b}}$ \\ Jacek P. Szaflik ${ }^{b}$ Agnieszka Cudnoch-Jędrzejewska ${ }^{a}$ \\ aDepartment of Experimental and Clinical Physiology, Center for Preclinical Research, Medical University of Warsaw, \\ Warsaw, Poland; 'bepartment of Ophthalmology, SPKSO Ophthalmic University Hospital, Medical University of \\ Warsaw, Warsaw, Poland
}

\section{Keywords}

Neuroprotection $\cdot$ Retina $\cdot$ Neurodegeneration $\cdot$ Retinal ganglion cells · Pathology using these factors. There are ongoing clinical trials with CNTF and NGF, but they have not yet been accepted for clinical use.

(c) 2021 S. Karger AG, Base

\begin{abstract}
Retinal ganglion cells (RGCs) play a crucial role in the visual pathway. As their axons form the optic nerve, apoptosis of these cells causes neurodegenerative vision loss. RGC death could be triggered by increased intraocular pressure, advanced glycation end products, or mitochondrial dysfunction. In this review, we summarize the role of some neuroprotective factors in RGC injury: ciliary neurotrophic factor (CNTF), nerve growth factor (NGF), brain-derived neurotrophic factor, vascular endothelial growth factor, pigment epithelium-derived factor, glial cell line-derived neurotrophic factor, and Norrin. Each, in their own unique way, prevents RGC damage caused by glaucoma, ocular hypertension, ischemic neuropathy, and even oxygen-induced retinopathy. These factors are produced mainly by neurons, leukocytes, glial cells, and epithelial cells. Neuroprotective factors act via various signaling pathways, including JAK/STAT, MAPK, TrkA, and TrkB, which promotes RGC survival. Many attempts have been made to develop therapeutic strategies
\end{abstract}

(C) 2021 S. Karger AG, Basel

www.karger.com/or

Karger $\stackrel{2}{=}$

\section{Introduction}

\section{The Anatomy of the Retina}

The retina is a complex structure that receives visual information. It consists of 10 layers, 9 inner layers are neural, and the outermost layer is the retinal pigment epithelium (RPE) [1]. In addition to light absorption, the RPE plays a role in nourishing the neuroretina, maintaining ionic equilibrium, and retinaldehyde metabolism [2]. The retina's neural part is composed of 5 major neuron types: bipolar cells, ganglion cells, horizontal cells, amacrine cells, and photoreceptors, which form a highly ordered 9-layer structure $[1,3]$. Recently, novel approaches to the structural organization of the neuroretina of the neuroretina have been described. A simplified division distinguishes 3 layers of neuron bodies containing nuclei and 2 layers of synaptic connections between them, mak- 
ing 5 layers in total [4]. Each type of retinal cell comprises a mosaic-like structure that provides a regular distribution throughout the retina [5]. Signal transduction in the retina begins with the isomerization of 11-cis retinal bounded to one of the visual pigments - rhodopsin for rods and cone opsin for cones. Next, the signal from the photoreceptors reaches the bipolar cells through glutamate-mediated synapses. This process is controlled by the horizontal cells. Bipolar cells convey the signal to the retinal ganglion cells (RGCs) [6-8]. The anatomy of the neural retina and receptors of the RGCs is shown in Figure 1.

\section{Retinal Ganglion Cells}

RGCs form the innermost layer of the neural retina and are the last cells of the neural net to receive visual stimulus within the eye. Their axons form the optic nerve, which conducts the visual information as impulses to the brain [6]. The electrical stimulus passed by the RGCs to the visual cortex consolidates the modifications made by previous neurons of the retina [9]. Therefore, RGCs play a vital and indispensable role in the process of vision and their injury can lead to irreversible blindness, as seen in advanced glaucoma [10]. Neuroprotection of these cells is a broadly studied therapy option that could eventually stop the development of disease [11].

\section{Mechanisms Involved in Retinal Ganglion Cell Damage}

As described above, the retina is a structure composed of neuronal cells which are prone to degeneration due to injury, aging, diabetes, and ocular hypertension $[12,13]$. The mechanisms involved in RGC protection are described in Figure 1. Neurotrophic factors contribute to the survival of RGCs in case of damage due to their antiapoptotic activity. Neurons that do not receive adequate signals undergo apoptosis [14]. It has been shown that advanced glycation end products, which are associated with aging and diabetes, induce activation of caspase 3 , one of the executioner caspases actives in apoptosis, in the retinal explant cells $[15,16]$. However, the presence of the active forms of caspases 3 and 9 in retinal cells exposed to high glucose levels incubated with neurotrophic factors (e.g., brain-derived neurotrophic factor $[\mathrm{BDNF}]$ ) was significantly lower than in the control group [17]. Elevated intraocular pressure (IOP), which is a relevant risk factor in glaucoma pathogenesis, leads to the expression of high-mobility group box 1 (HMGB1) protein and then leads to inflammasome activation which triggers further inflammation [18]. Increased IOP also induces phos- phorylation of antiapoptotic cytoplasmic protein 14-3-3. Phosphorylation of 14-3-3 enables the dephosphorylation and consequently the activation of the proapoptotic protein Bcl-2 associated agonist of cell death (BAD) [19]. Another study showed that elevated IOP enhances Bax expression, which is also a proapoptotic factor [20]. Apoptosis in glaucoma and diabetic retinopathy can be induced directly by inflammatory cytokines such as tumor necrosis factor-alpha (TNFa), as well as membranebound Fas-ligand (FasL) [21-23]. Interestingly, soluble FasL appears to have a neuroprotective activity [22]. It is worth noting that expression of FasL and other proapoptotic factors such as active caspases 3 and 8 was upregulated in the retina of diabetic patients compared with healthy individuals and no difference was observed in the expression of antiapoptotic markers: B-cell lymphomaextra large (Bcl-xL), FLICE-like inhibitory protein (FLIP), and cyclooxygenase-2 (COX2) [24]. Also, mitochondrial dysfunction might play a role in RGC death [25]. Mutations in mitochondrial DNA (mtDNA) caused by increased IOP lead to the progressive loss of RGCs. This damage includes flaws in the electron transport chain and consequently alteration in the reactive oxygen species (ROS) levels, leading to further mtDNA damage. Mutant mitochondria also do not provide enough adenosine triphosphate production. Ultimately, even when the IOP lowers, mitochondrial derangement leads to the apoptosis of RGCs [26, 27]. Aging also leads to elevated levels of ROS, which is one of the major correlations of gradual vision impairment in the elderly [28]. Eventually, RGCs are lost physiologically with increasing age [29].

\section{Aim of the Review}

A few proteins have been shown to demonstrate neuroprotective properties in response to retina damage. This review summarizes the up-to-date knowledge about their function in protecting RGCs from degeneration. Also, we have outlined the recent experimental and clinical trials which explore the therapeutic possibilities of neuroprotective factors in acute neuropathies such as optic nerve crush and in chronic neuropathies such as glaucoma.

\section{Proteins with Neuroprotective Properties}

\section{Ciliary Neurotrophic Factor}

Ciliary neurotrophic factor (CNTF) is a neuropoietic cytokine that belongs to the IL- 6 family. It binds to a gp130 receptor to activate the JAK/STAT and MAPK 


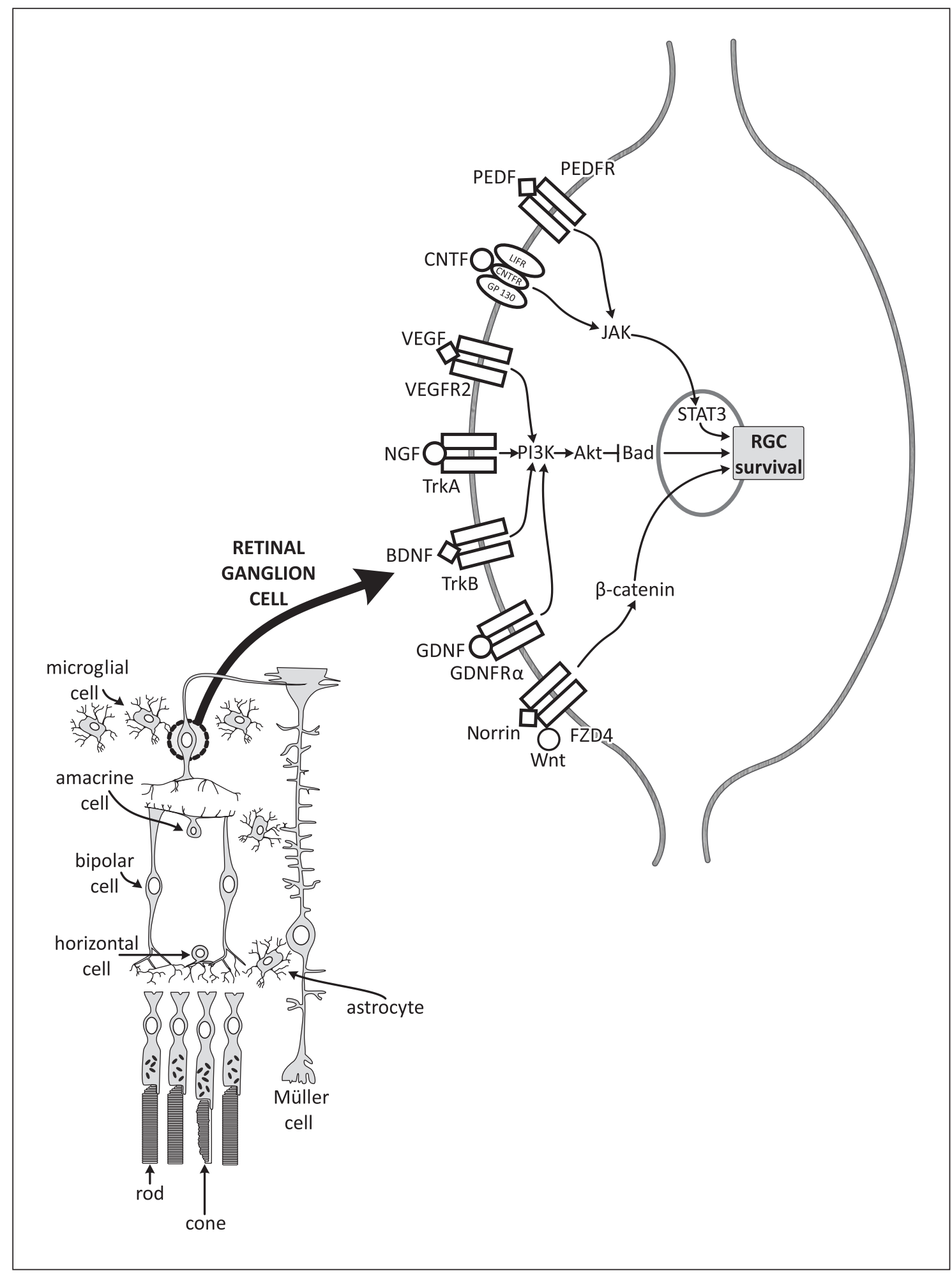

Fig. 1. The anatomy of the neural retina and receptors of the RGCs. The pathways are activated by neuroprotective factors. 
pathways [30]. These signaling pathways regulate gene expression to stimulate neuron regeneration in mice and zebra fish [31, 32]. In the eye, CNTF exerts a neuroprotective effect on photoreceptors and the RGCs by stimulating regeneration [33]. It was also shown that CNTF deprivation does not cause neurodegeneration in the retina [34]. However, CNTF administration can significantly increase the survival of retinal cells [35]. Many studies have been conducted to define the best way of CNTF delivery to the retina.

Intravitreal injection of CNTF in a murine model of nonarteritic anterior ischemic optic neuropathy revealed a significant increase in the survival rate of RGCs compared with the control group [36]. An increase in the survival of RGCs was also noted when intravitreal injection of CNTF was combined with cyclic adenosine monophosphate analog [37]. Two administration routes were compared in an in vitro study of RGCs with $\mathrm{H}_{2} \mathrm{O}_{2}$-induced injury: (i) using lentiviral vectors carrying the CNTF gene and (ii) adding the protein to the culture medium. Although a neuroprotective effect was observed in both groups, there was no significant difference in the survival of RGCs between the 2 methods [35].

Adeno-associated viral vector (AAV)-mediated CNTF gene transfer has been proven to support axon regeneration of RGCs after optic nerve crush [38, 39]. However, Hellström et al. [40] pointed out that the effect of CNTF administration via adeno-associated viral vector is delayed because of the time needed to start gene expression. To maintain the therapeutic effect during the delay, a combined genetic and pharmacological treatment (the administration of recombinant CNTF with cyclic adenosine monophosphate analog) was proposed which turned out to be very effective in protecting the RGCs after nervous tissue trauma in rats [40].

Neural stem cells can be genetically modified to produce more CNTF and can then be grafted into the vitreous body to exert a neuroprotective effect as shown in a mouse model after optic nerve crush [41]. When neural stem cells that produce glial cell line-derived neurotrophic factor (GDNF) were added to the CNTF therapy, the proteins had a synergic effect in the protection of RGCs [42].

Another method of modulating CNTF expression is through the inhibition of the purinergic receptor $\mathrm{P} 2 \mathrm{X} 7$ (P2X7R) [43]. The P2X7R is an ionotropic receptor activated by extracellular adenosine triphosphate, which promotes the synthesis of various pro-inflammatory mediators that support neuroinflammation which later leads to neurodegeneration. The P2X7R can be found on microg- lial cells, astrocytes, and neurons throughout the central nervous system including the retina, and also in other structures of the globe such as the cornea, lens cells, etc. $[43,44]$. Antagonizing P2X7R weakens the inflammatory response and leads to neuroprotection [43, 45-47]. Recently, it was shown that chronic application of eye drops containing P2XR7 antagonist in mice with glaucoma decreased the number of activated microglia and prevented the loss of RGCs [46]. Inhibiting P2X7R has been shown to increase the levels of CNTF in neurons. However, delivering to mice Brilliant Blue $G$, the well-known P2X7R antagonists, exerts no neurogenic effect, despite increasing pro-neurogenic CNTF due to the simultaneous inducement of counteracting growth factors [48].

\section{Nerve Growth Factor}

Nerve growth factor (NGF) is a neurotrophic factor secreted by multiple cells: neurons, Schwann cells, and oligodendrocytes of the nervous tissue; mast cells, T cells, and macrophages of the immune system; keratinocytes, melanocytes, and fibroblasts of the skin; and even by smooth muscle cells. Its functions include regulating neurogenesis and apoptosis, promoting neuron plasticity, modulating a neuron's response to heat and pain, and participating in the process of neuroinflammation with nociceptor activation [49]. There are 2 NGF receptors in the retina: the RGCs express the transmembrane tyrosine receptor kinase A (TrkA), while glial cells express the p75 neurotrophin receptor (p75 ${ }^{\mathrm{NTR}}$ ). NGF, like BDNF, is produced not only in the retina but also in the brain, from where it is transported via the neurons of the optic disc. Disturbance in this pathway leads to altered NGF levels in the retina [50]. NGF can be blocked by a2Macroglobulin, which precludes NGF interaction with its receptor. A lack of NGF trophic function leads to a decrease in the survival rate of retinal cells [51].

Attempts to prevent RGC death in glaucoma by NGF administration did not meet expected outcomes, probably due to NGF activating the receptors of the opposite action - TrkA and p75 ${ }^{\mathrm{NTR}}$ [52]. Mesentier-Louro et al. [53] studied the effect of optic nerve crush on the upregulation of NGF, proNGF, and $\mathrm{p} 75^{\mathrm{NTR}}$. It was proposed that while NGF exerts a neuroprotective action by activating TrkA, proNGF activates $\mathrm{p} 75^{\mathrm{NTR}}$ to promote apoptosis, with the overall result being RGC degeneration [53]. Therefore, effective treatment should include a drug that selectively activates the neuroprotective TrkA or inhibits the proapoptotic $\mathrm{p} 75^{\mathrm{NTR}}[52,54]$. On the other hand, Guo et al. [55] showed that topical administration of recombinant human NGF (rh-NGF) does exert significant neuro- 
protection in animal optic neuropathy models. The described mechanism involves inhibition of the secondary neurodegenerative processes [55].

\section{Brain-Derived Neurotrophic Factor}

BDNF is a neurotrophin produced by neurons in the retina, such as RGCs, amacrine cells, astrocytes, retinal glial cells (Müller cells), and photoreceptors [56, 57]. BDNF can also be transported between the brain and the retina via the optic nerve $[58,59]$. Its primary functions in the nervous system include controlling neural development, modulating synaptogenesis, and neuroprotection [60]. In the retina, BDNF plays a vital role in vision signaling development by regulating laminar refinement in the dendrites of RGCs, which leads to the proper formation of the retinal structure [61]. In mature individuals, endogenous BDNF exerts neuroprotective effects on RGCs by protecting dendritic fields and reducing vision loss after ocular hypertension-induced injury, which was observed in animal models of ocular hypertension and glaucoma $[58,62]$. Another function of BDNF is protection of the retina cells from injuries caused by hypoxia and glucose deprivation [63].

Tropomyosin receptor kinase B (TrkB), the BDNF receptor [64], may also be activated by specific immunoglobulins. Administration of mouse monoclonal antibodies, which act as $\operatorname{TrkB}$ exogenous selective agonists, promotes antiapoptotic activity [65]. The Src homology region 2-containing protein tyrosine phosphatase 2 (Shp2) has been identified as playing a role in BDNFTrkB signaling. Shp2-mediated TrkB dephosphorylation inhibits the signaling pathway and thus leads to decreased survival of the RGCs. Modulating Shp2 activity appears to be a new target in experimental glaucoma therapy [66].

Similar to CNTF, BDNF expression may also be influenced by purinergic receptor signaling. P2X7R, mentioned above, has been shown to influence BDNF action: antagonizing P2X7R leads to TrkB activation [67]. BDNF expression can also be modulated by purinergic receptors that belong to the P1 family of metabotropic receptors activated by extracellular adenosine. There is a complex crosstalk between the P1A1 receptors, the P1A2A receptors, interleukin- 6 expression, and BDNF expression, which is not fully understood [68]. Nevertheless, antagonism of the P1A1 and P1A2A receptors is considered to be a potential future therapeutic option for neurodegenerative diseases of the central nervous system $[44,69]$.

BDNF has been used therapeutically in animal models of glaucoma. However, intravitreal administration of a recombinant protein has a time-limited effect due to the downregulation of TrkB that follows [70-72]. To counteract this effect, a novel gene therapy transferring both the BDNF and the TrkB gene has been proposed and was proven to promote long-term survival of the RGCs in a rodent model of optic nerve injury [73].

\section{Vascular Endothelial Growth Factor}

Vascular endothelial growth factor (VEGF) is a family of proangiogenic factors that includes 7 proteins: VEGF $\mathrm{A}, \mathrm{B}, \mathrm{C}, \mathrm{D}, \mathrm{E}, \mathrm{F}$, and placental growth factor. The most widely distributed in human tissue is VEGF A, which is commonly referred to simply as "VEGF" [74]. In the eye, it is secreted by multiple cells, such as cells of the vascular and RPE, Müller cells, astrocytes, and RGCs. VEGF binds to VEGF receptors 1 (VEGFR-1) and 2 (VEGFR-2) [75]. The primary VEGF functions include promotion of angiogenesis, vasodilation, and increasing vascular permeability [76]. It also plays a role in the pathomechanism of ocular retinopathies, e.g., exudative age-related macular degeneration and diabetic macular edema [75]. However, VEGF exhibits neuroprotective properties. It was shown that VEGF-A binding to VEGFR-2 and activation of the PI3-K/ACT pathway was necessary to promote the survival of the RGCs. This action was not only neuroprotective but also sufficient for glaucoma prevention [77]. There are 2 isoforms of VEGF-A (VEGF-A165a and VEGF-A165b). VEGF-A165b is of greater importance in neuroprotection and may be useful in treating neuropathies, but it also exhibits angiogenic activity [78]. Therefore, the administration of VEGF in ocular disorders for its neuroprotective effect is disputable due to the high chance of vascular adverse effects. In vitro studies showed that non-inflammatory VEGF121 modified to be bound to a cell membrane, thus exerting an autocrine effect only, was beneficial for the survival of RGCs and also lacked the ability to bind to other cells [79]. Surprisingly, the administration of ranibizumab, a humanized antibody that binds VEGF-A after optic nerve injury, attenuates the loss of RGCs. A negative correlation was shown between VEGF concentration in the aqueous humor, peripheral blood, and the number of surviving cells [80].

\section{Pigment Epithelium-Derived Factor}

Pigment epithelium-derived factor (PEDF) in the retina is secreted by the Müller cells and exhibits antiangiogenic and neuroprotective activity. It can prevent damage to RGCs and stimulate axogenesis [81-83]. PEDF inhibition has been shown to decrease the survival of RGCs in vitro [84, 85]. Several mechanisms of action have been proposed: caspase 2 suppression, upregulation of the un- 
coupling of protein 2, prevention of mitochondrial dysfunction, and activation of the STAT3 pathway [86-89]. It was shown that increased (IOP) leads to the upregulation of PEDF and its receptor - PEDF-R, thus inhibiting apoptosis of RGCs [90]. Also, the method of administration may have an impact on effectiveness. Vigneswara et al. [91] investigated the difference between daily eye drop delivery and weekly intravitreal injections in rats after optic nerve crush and showed the greater effectiveness of daily eye drop delivery for the survival of RGCs. Gene therapy through lentiviral vectors has also been proven to attenuate the apoptosis of RGCs in ocular hypertension models [92].

\section{Glial Cell Line-Derived Neurotrophic Factor}

Four proteins belonging to the glial cell line-derived neurotrophic factor (GDNF) family of ligands have been described: GDNF, artemin, neurturin, and persephin. They play a vital role in the development and function of the nervous system, in spermatogenesis, and in renal growth $[93,94]$. Many studies focused on the role of GDNF family of ligands in the retina, proving their neuroprotective effect on photoreceptors and RGCs $[95,96]$. Post-injury apoptosis of RGCs may be promoted by extracellular glutamate, whereas GDNF and neurturin prevent the proapoptotic cascade by upregulating the glutamate transporter levels which leads to the uptake of the glutamate by retinal cells [97]. In the rodent models of glaucoma, administration of GDNF-loaded microspheres by intravitreal injections resulted in increased density of the RGCs [98], increased axon survival, and lowered proinflammatory glial cell activation [99]. After adding vitamin $\mathrm{E}$ to the microsphere structure, an additive effect can be observed due to the vitamin's antioxidant and antiproliferative properties [100].

\section{Norrin}

Norrin is a protein constitutively expressed by the Müller cells in the retina. It has functional similarity to growth factors, and its reported functions include angiogenesis stimulation and neuroprotection [101]. Norrin binds to the Frizzled-4 (FZD4) receptors to activate the $\mathrm{Wnt} / \beta$-catenin signaling pathway, which promotes cell survival. It has been proven that inhibiting this signaling pathway (through dickkopf- 1 , a Wnt/ $\beta$-catenin inhibitor) suppresses the action of Norrin $[102,103]$. Another proposed mechanism of neuroprotection involves the leukemia inhibitory factor (LIF), which is necessary for the gliosis of Müller cells - a reaction of neural cells that contributes to the maintenance of retinal homeostasis in physiological and pathological states [104]. After excitotoxic damage, Norrin induces LIF expression in retinal neurons, which in turn stimulates Müller cells to secrete protective factors - endothelin 2 (ET-2) and fibroblast growth factor 2 (FGF2) [105].

The neuroprotective effects of Norrin were shown in both acute and chronic neuropathies. After protease-mediated injury of RGCs, the protein acts via the Wnt/ $\beta$ catenin signaling pathway to increase the survival of RGCs [106]. In a mouse model of glaucoma, genetically modified individuals with overexpression of the Norrin gene showed greater survival of RGCs [107].

Norrin has also been studied in a rodent model of oxygen-induced retinopathy. It was shown that intravitreal injections of Norrin correlated with a higher density of RGCs and a thicker nerve fiber layer [108].

\section{Eye Disease Therapies Based on Neuroprotective Factors in Clinical Trials}

As of today, little is known about the translation of neuroprotective factor therapies into clinical use. New treatment strategies are researched for diseases primarily caused by the degeneration of RGCs such as glaucoma, and other ophthalmic diseases such as macular degeneration, retinitis pigmentosa, ischemic optic neuropathy, macular telangiectasia, and cystoid macular edema (Table 1). The only tested CNTF-based therapy for the abovementioned diseases, with the exception of cystoid macular edema, is the NT-501 encapsulated cell implant-based therapy. NT-501 is an implant containing immortal cells, genetically modified to express CNTF, embedded on a polymer scaffold. It is inserted into the eye globe through the inferotemporal quadrant of the sclera and affixed with a single suture during a $15-\mathrm{min}$ procedure. Although many studies on phase 2 were conducted on this implant, no further phase 3 trials have been registered at https:// clinicaltrials.gov/ [109-113]. Currently, an extension study is conducted among patients with Macular Telangiectasia Type 2, an idiopathic disease considered as primarily neurodegenerative [114]. This extension study was justified by the positive outcome of previous investigations (NCT03071965) [113]. Another therapy, with topical administration of human recombinant NGF (rhNGF), appears to be in the early stage of introduction to clinical use [115]. Patients receive eye drops which penetrate the conjunctival sac to reach the inner part of the globe. This approach was proven as safe and then tested on neurotrophic keratitis, which is not associated with 
Table 1. Clinical trials using neuroprotective factor-based therapies registered at clinicaltrials.gov (up to June 2020)

\begin{tabular}{|c|c|c|c|c|c|c|}
\hline Factor & Group of patients & $\begin{array}{l}\text { Clinicaltrials.Gov } \\
\text { identifier }\end{array}$ & Intervention & $\begin{array}{l}\text { Phase of clinical } \\
\text { trial }\end{array}$ & $\begin{array}{l}\text { Year of } \\
\text { study start }\end{array}$ & Results \\
\hline \multirow[t]{10}{*}{ CNTF } & Glaucoma & NCT01408472 & \multirow{10}{*}{$\begin{array}{l}\text { NT-501 } \\
\text { Encapsulated cell } \\
\text { therapy }\end{array}$} & 1 & 2011 & Not published \\
\hline & & NCT02862938 & & 2 & 2016 & \\
\hline & Retinitis pigmentosa & NCT00063765 & & 1 & 2003 & Positive safety profile [100] \\
\hline & $\begin{array}{l}\text { Retinitis pigmentosa (early } \\
\text { stage) }\end{array}$ & NCT00447980 & & 2 & 2007 & $\begin{array}{l}\text { Not significant changes in visual field and } \\
\text { visual acuity }[100,102]\end{array}$ \\
\hline & $\begin{array}{l}\text { Retinitis pigmentosa (late } \\
\text { stage) }\end{array}$ & NCT00447993 & & 2 & 2007 & $\begin{array}{l}\text { Not significant changes in visual field and } \\
\text { visual acuity except decrease in vision } \\
\text { sensivity in high-dose treated patients } \\
{[102]}\end{array}$ \\
\hline & $\begin{array}{l}\text { Macular degeneration and } \\
\text { geographic atrophy }\end{array}$ & NCT00447954 & & 2 & 2007 & $\begin{array}{l}\text { Structural and functional improvements } \\
\text { in retina }[99,100]\end{array}$ \\
\hline & Ischemic optic neuropathy & NCT01411657 & & 1 & 2011 & Not published \\
\hline & \multirow{3}{*}{$\begin{array}{l}\text { Macular telangiectasia type } \\
2\end{array}$} & NCT01327911 & & 1 & 2011 & Positive safety profile [101] \\
\hline & & NCT01949324 & & 2 & 2003 & $\begin{array}{l}\text { Slower progression of retinal degradation } \\
\text { [103] }\end{array}$ \\
\hline & & NCT03071965 & & 2 (extension study) & 2017 & Not published \\
\hline \multirow[t]{4}{*}{ NGF } & Glaucoma & NCT02855450 & \multirow{4}{*}{$\begin{array}{l}\text { Topical } \\
\text { administration of } \\
\text { rhNGF drops }\end{array}$} & 1 & 2016 & Not published \\
\hline & Retinitis pigmentosa & NCT02110225 & & 2 & 2014 & $\begin{array}{l}\text { Results published on https://clinicaltrials. } \\
\text { gov/without analysis }\end{array}$ \\
\hline & $\begin{array}{l}\text { Retinitis pigmentosa and } \\
\text { cystoid macular edema }\end{array}$ & NCT02609165 & & 2 & 2015 & Not published \\
\hline & Healthy volunteers & NCT01744704 & & 1 & 2012 & Positive safety profile [105] \\
\hline
\end{tabular}

CNTF, ciliary neurotrophic factor; NGF, nerve growth factor; rhNGF, recombinant human nerve growth factor.

damage to RGCs but with impairment of the ophthalmic branch of the trigeminal nerve innervating the cornea $[115,116]$. The phase 2 study suggested that rh-NGF could be effective in neurotrophic keratitis treatment [117]. Drugs acting as a decoy to VEGF are currently tested as an intravitreal therapy mainly for macular degeneration patients $[118,119]$. The collective inhibitor of VEGF and PDGF administered intravitreally was also tested, and results revealed that the combination of both leads to relatively higher visual activity compared with monotherapy [120]. In some studies, ranibizumab, a VEGF-A antibody, was combined with novel drugs such as pazopanib eye drops (a VEGFR tyrosine kinase inhibitor), but no significant improvement was observed compared to ranibizumab only [121]. Altogether, a significant number of studies are investigating VEGF-related agents, based on the number of searches at https://clinicaltrials. gov/; however, all of them focus on inhibiting neovascu- larization. No studies on neuroprotective therapy based on VEGF were found. As for P2X7R, even though preclinical data shows promise, no clinical trials targeting this receptor in therapy of ophthalmic diseases have been registered.

However, neurotrophic factors are not the only agents presenting neuroprotective properties. Citicoline (cytidine $5^{\prime}$-diphosphocholine) is currently used as a dietary supplement as it has been proven to mitigate symptoms of neurological diseases such as Alzheimer's disease. Experimental data show that citicoline exhibits neuroprotective, neurorestorative, and regenerative activity in retinal cells in vitro and in animal models. Also, clinical trials have confirmed positive outcomes from the use of citicoline in patients with glaucoma [122]. Some reports indicate that simvastatin exhibits neuroprotective properties by inhibiting stress-related intracellular pathways in microglia and astrocytes in animal models. This action 
results in attenuated inflammation in the retina, which may protect RGCs from death $[123,124]$. The coenzyme $\mathrm{Q}$ appears to have neuroprotective properties presumably by acting as a ROS scavenger $[125,126]$. Overall, this brief overview of a few examples suggests that well-known substances might be useful in the treatment of damage to RGCs and this area needs further study.

\section{Conclusion}

Neurodegeneration is a pathomechanism that underlies many ophthalmic diseases, such as glaucoma, diabetic retinopathy, age-related macular degeneration, and retinal ischemia-reperfusion injury. As of today, modulating the expression of neuroprotective factors is not the treatment option for ophthalmology patients. However, with many promising results from preclinical studies, it may become a therapy option for some diseases in the future. It is worth remembering that neuroprotection can also be stimulated by substances other than neuroprotective factors, such as P2X7R antagonists, citicoline, statins, coenzyme Q, and others. However, their detailed description exceeds the scope of this review. Another important matter for researchers is to create a fully reliable model of injury to RGCs which will enable a better understanding of the efficacy of neuroprotective factors and their full potential. This review summarizes the most significant results and covers the basic foundation knowledge necessary to understand the subject. It is essential for ophthalmology specialists to stay up to date with recent findings, such as the introduction of neuroprotective factors. However, this vast subject still needs further investigation which might provide clinicians with the information needed to treat patients with therapies based on neuroprotective factors. Further studies are crucial to fully understand the impact of these proteins on RGCs.

\section{Acknowledgment}

We thank Marcin Kumosa for help with the graphic design of Figure 1.

\section{Conflict of Interest Statement}

The authors have no conflicts of interest to declare.

\section{Funding Sources}

Research subject implemented with CePT infrastructure financed by the European Regional Development Fund within the "Innovative economy for 2007-2013" operational program.

\section{Author Contributions}

All the authors contributed to the review design. Ewa Fudalej, Magdalena Justyniarska, and Jacek Dziedziak prepared the first draft of the manuscript, which was then revised critically by Kaja Kasarełło and Agnieszka Cudnoch-Jędrzejewska, who both focused on the part describing the experimental/preclinical data, and Jacek Szaflik, who focused on the clinical data. All the authors contributed to the correction process leading to the final version of the manuscript. All the authors approved the final version of the manuscript to be published.

\section{References}

1 Gupta MP, Herzlich AA, Sauer T, Chan CC. Retinal anatomy and pathology. Dev Ophthalmol. 2016;55:7-17.

2 Strauss $\mathrm{O}$. The retinal pigment epithelium in visual function. Physiol Rev. 2005;85(3):845-81.

3 Masland R. Neuronal diversity in the retina. Curr Opin Neurobiol. 2001;11(4):431-6.

4 Baden T, Euler T, Berens P. Understanding the retinal basis of vision across species. Nat Rev Neurosci. 2020;21(1):5-20.

5 Rockhill RL, Euler T, Masland RH. Spatial order within but not between types of retinal neurons. Proc Natl Acad Sci U S A. 2000; 97(5):2303-7.
6 Sanes JR, Masland RH. The types of retinal ganglion cells: current status and implications for neuronal classification. Annu Rev Neurosci. 2015;38:221-46.

7 Nickle B, Robinson PR. The opsins of the vertebrate retina: insights from structural, biochemical, and evolutionary studies. Cell Mol Life Sci. 2007 Nov;64:2917-32.

8 Hoon M, Okawa H, Della Santina L, Wong RO. Functional architecture of the retina: development and disease. Prog Retin Eye Res. 2014;42:44-84.

9 Kolb H. Morphology and circuitry of ganglion cells. Salt Lake City, UT: University of Utah Health Sciences Center; 1995.
10 Gupta D, Musch DC, Niziol LM, Chen PP. Refusal of trabeculectomy for the fellow eye in Collaborative Initial Glaucoma Treatment Study (CIGTS) participants. Am J Ophthalmol. 2016;166(8):1-7.

11 Gauthier AC, Liu J. Neurodegeneration and neuroprotection in glaucoma. Yale J Biol Med. 2016;89(1):73-9.

12 Syc-Mazurek SB, Libby RT. Axon injury signaling and compartmentalized injury response in glaucoma. Prog Retin Eye Res. 2019; 73:100769.

13 Guedes G, Tsai JC, Loewen NA. Glaucoma and aging. Curr Aging Sci. 2011;4(2):110-7. 
14 Claes M, De Groef L, Moons L. Target-derived neurotrophic factor deprivation puts retinal ganglion cells on death row: cold hard evidence and caveats. Int J Mol Sci. 2019 Sep; 20(17):4314.

15 Lecleire-Collet A, Tessier LH, Massin P, Forster V, Brasseur G, Sahel JA, et al. Advanced glycation end products can induce glial reaction and neuronal degeneration in retinal explants. Br J Ophthalmol. 2005;89(12):1631-3.

16 Moldogazieva NT, Mokhosoev IM, Mel'nikova TI, Porozov YB, Terentiev AA. Oxidative stress and advanced lipoxidation and glycation end products (ALEs and AGEs) in aging and age-related diseases. Oxid Med Cell Longev. 2019;2019:3085756.

17 Oshitari T, Yoshida-Hata N, Yamamoto S. Effect of neurotrophic factors on neuronal apoptosis and neurite regeneration in cultured rat retinas exposed to high glucose. Brain Res. 2010;1346:43-51.

18 Chi W, Chen H, Li F, Zhu Y, Yin W, Zhuo Y. HMGB1 promotes the activation of NLRP3 and caspase- 8 inflammasomes via NF- $\kappa B$ pathway in acute glaucoma. J Neuroinflammation. 2015;12:137.

19 Yang X, Luo C, Cai J, Pierce WM, Tezel G. Phosphorylation-dependent interaction with 14-3-3 in the regulation of bad trafficking in retinal ganglion cells. Invest Ophthalmol Vis Sci. 2008;49(6):2483-94.

20 Coassin M, Lambiase A, Sposato V, Micera A, Bonini S, Aloe L. Retinal p75 and bax overexpression is associated with retinal ganglion cells apoptosis in a rat model of glaucoma. Graefes Arch Clin Exp Ophthalmol. 2008; 246(12):1743-9.

21 Roh M, Zhang Y, Murakami Y, Thanos A, Lee SC, Vavvas DG, et al. Etanercept, a widely used inhibitor of tumor necrosis factor- $a$ (TNF- $\alpha)$, prevents retinal ganglion cell loss in a rat model of glaucoma. PLoS One. 2012; 7(7):e40065.

22 Gregory MS, Hackett CG, Abernathy EF, Lee KS, Saff RR, Hohlbaum AM, et al. Opposing roles for membrane bound and soluble Fas ligand in glaucoma-associated retinal ganglion cell death. PLoS One. 2011;6(3):e17659.

23 Joussen AM, Doehmen S, Le ML, Koizumi K, Radetzky S, Krohne TU, et al. TNF-alpha mediated apoptosis plays an important role in the development of early diabetic retinopathy and long-term histopathological alterations. Mol Vis. 2009;15:1418-28.

24 Valverde AM, Miranda S, García-Ramírez M, González-Rodriguez Á, Hernández C, Simó R. Proapoptotic and survival signaling in the neuroretina at early stages of diabetic retinopathy. Mol Vis. 2013;19:47-53.

25 Osborne NN, Núñez-Álvarez C, Joglar B, Del Olmo-Aguado S. Glaucoma: focus on mitochondria in relation to pathogenesis and neuroprotection. Eur J Pharmacol. 2016;787: $127-33$.
$26 \mathrm{Wu} \mathrm{JH}$, Zhang SH, Nickerson JM, Gao FJ, Sun $\mathrm{Z}$, Chen XY, et al. Cumulative mtDNA damage and mutations contribute to the progressive loss of RGCs in a rat model of glaucoma. Neurobiol Dis. 2015;74:167-79.

27 Pilz YL, Bass SJ, Sherman J. A review of mitochondrial optic neuropathies: from inherited to acquired forms. J Optom. 2017;10(4):20514.

28 Saccà SC, Cutolo CA, Rossi T. Visual defects and ageing. Subcell Biochem. 2019;91:393434.

29 Neufeld AH, Gachie EN. The inherent, agedependent loss of retinal ganglion cells is related to the lifespan of the species. Neurobiol Aging. 2003;24(1):167-72.

30 Bauer S, Kerr BJ, Patterson PH. The neuropoietic cytokine family in development, plasticity, disease and injury. Nat Rev Neurosci. 2007;8(3):221-32.

31 Elsaeidi F, Bemben MA, Zhao XF, Goldman D. Jak/Stat signaling stimulates zebrafish optic nerve regeneration and overcomes the inhibitory actions of Socs 3 and Sfpq. J Neurosci. 2014;34(7):2632-44.

32 Smith PD, Sun F, Park KK, Cai B, Wang C, Kuwako K, et al. SOCS3 deletion promotes optic nerve regeneration in vivo. Neuron. 2009;64(5):617-23.

33 Wen R, Tao W, Li Y, Sieving PA. CNTF and retina. Prog Retin Eye Res. 2012;31(2):13651.

34 Takahashi R, Yokoji H, Misawa H, Hayashi $\mathrm{M}, \mathrm{Hu}$ J, Deguchi T. A null mutation in the human CNTF gene is not causally related to neurological diseases. Nat Genet. 1994;7(1): 79-84.

35 Wang WJ, Jin W, Yang AH, Chen Z, Xing YQ Protective effects of ciliary neurotrophic factor on the retinal ganglion cells by injure of hydrogen peroxide. Int J Ophthalmol. 2018; 11(6):923-8.

36 Mathews MK, Guo Y, Langenberg P, Bernstein SL. Ciliary neurotrophic factor (CNTF)mediated ganglion cell survival in a rodent model of non-arteritic anterior ischaemic optic neuropathy (NAION). Br J Ophthalmol. 2015;99(1):133-7.

37 Drummond ES, Rodger J, Penrose M, Robertson D, Hu Y, Harvey AR. Effects of intravitreal injection of a Rho-GTPase inhibitor (BA210 ), or CNTF combined with an analogue of cAMP, on the dendritic morphology of regenerating retinal ganglion cells. Restor Neurol Neurosci. 2014;32(3):391-402.

38 Cen LP, Liang JJ, Chen JH, Harvey AR, Ng TK, Zhang M, et al. AAV-mediated transfer of RhoA shRNA and CNTF promotes retinal ganglion cell survival and axon regeneration. Neuroscience. 2017;343:472-82.

39 Yungher BJ, Ribeiro M, Park KK. Regenerative responses and axon pathfinding of retinal ganglion cells in chronically injured mice. Invest Ophthalmol Vis Sci. 2017;58(3):1743-50.
40 Hellström M, Pollett MA, Harvey AR. Postinjury delivery of rAAV2-CNTF combined with short-term pharmacotherapy is neuroprotective and promotes extensive axonal regeneration after optic nerve trauma. J Neurotrauma. 2011;28(12):2475-83.

41 Flachsbarth K, Kruszewski K, Jung G, Jankowiak W, Riecken K, Wagenfeld L, et al. Neural stem cell-based intraocular administration of ciliary neurotrophic factor attenuates the loss of axotomized ganglion cells in adult mice. Invest Ophthalmol Vis Sci. 2014;55(11):702939.

42 Flachsbarth K, Jankowiak W, Kruszewski K, Helbing S, Bartsch S, Bartsch U. Pronounced synergistic neuroprotective effect of GDNF and CNTF on axotomized retinal ganglion cells in the adult mouse. Exp Eye Res. 2018; 176:258-65.

43 Dutot M, Olivier E, Wakx A, Rat P. The role of the P2X7 receptor in ocular stresses: a potential therapeutic target. Vision. 2017;1(2): 14.

44 Cieślak M, Wojtczak A. Role of purinergic receptors in the Alzheimer's disease. Purinergic Signal. 2018;14(4):331-44.

45 Ryu JK, McLarnon JG. Block of purinergic $\mathrm{P} 2 \mathrm{X}(7)$ receptor is neuroprotective in an animal model of Alzheimer's disease. Neuroreport. 2008;19(17):1715-9.

46 Romano GL, Amato R, Lazzara F, Porciatti V, Chou TH, Drago F, et al. P2X7 receptor antagonism preserves retinal ganglion cells in glaucomatous mice. Biochem Pharmacol. 2020;180:114199.

47 Fletcher EL, Wang AY, Jobling AI, Rutar MV, Greferath U, Gu B, et al. Targeting P2X7 receptors as a means for treating retinal disease. Drug Discov Today. 2019;24(8):1598-605.

48 Kang SS, Keasey MP, Hagg T. P2X7 receptor inhibition increases CNTF in the subventricular zone, but not neurogenesis or neuroprotection after stroke in adult mice. Transl Stroke Res. 2013;4(5):533-45.

49 Aarão TLS, de Sousa JR, Falcão ASC, Falcão LFM, Quaresma JAS. Nerve growth factor and pathogenesis of leprosy: review and update. Front Immunol. 2018;9:939.

50 Tirassa P, Rosso P, Iannitelli A. Ocular nerve growth factor (NGF) and NGF eye drop application as paradigms to investigate NGF neuroprotective and reparative actions. Methods Mol Biol. 2018;1727:19-38.

51 Bai Y, Sivori D, Woo SB, Neet KE, Lerner SF, Saragovi HU. During glaucoma, alpha2-macroglobulin accumulates in aqueous humor and binds to nerve growth factor, neutralizing neuroprotection. Invest Ophthalmol Vis Sci. 2011;52(8):5260-5.

52 Shi Z, Birman E, Saragovi HU. Neurotrophic rationale in glaucoma: a TrkA agonist, but not NGF or a p75 antagonist, protects retinal ganglion cells in vivo. Dev Neurobiol. 2007;67(7): 884-94. 
53 Mesentier-Louro LA, De Nicolò S, Rosso P, De Vitis LA, Castoldi V, Leocani L, et al. Time-dependent nerve growth factor signaling changes in the rat retina during optic nerve crush-induced degeneration of retinal ganglion cells. Int J Mol Sci. 2017;18(1):98.

54 Bai Y, Dergham P, Nedev H, Xu J, Galan A, Rivera JC, et al. Chronic and acute models of retinal neurodegeneration TrkA activity are neuroprotective whereas p75NTR activity is neurotoxic through a paracrine mechanism. J Biol Chem. 2010;285(50):39392-400.

55 Guo L, Davis BM, Ravindran N, Galvao J, Kapoor N, Haamedi N, et al. Topical recombinant human Nerve growth factor (rh-NGF) is neuroprotective to retinal ganglion cells by targeting secondary degeneration. Sci Rep. 2020;10(1):3375.

56 Telegina DV, Kolosova NG, Kozhevnikova OS. Immunohistochemical localization of NGF, BDNF, and their receptors in a normal and AMD-like rat retina. BMC Med Genomics. 2019;12(Suppl 2):48.

57 Ghazi-Nouri SM, Ellis JS, Moss S, Limb GA, Charteris DG. Expression and localisation of BDNF, NT4 and TrkB in proliferative vitreoretinopathy. Exp Eye Res. 2008;86(5):819-27.

58 Feng L, Chen H, Yi J, Troy JB, Zhang HF, Liu $\mathrm{X}$. Long-term protection of retinal ganglion cells and visual function by brain-derived neurotrophic factor in mice with ocular hypertension. Invest Ophthalmol Vis Sci. 2016; 57(8):3793-802.

59 Caleo M, Menna E, Chierzi S, Cenni MC, Maffei L. Brain-derived neurotrophic factor is an anterograde survival factor in the rat visual system. Curr Biol. 2000;10(19):1155-61.

60 Kowiański P, Lietzau G, Czuba E, Waśkow M, Steliga A, Moryś J. BDNF: a key factor with multipotent impact on brain signaling and synaptic plasticity. Cell Mol Neurobiol. 2018; 38(3):579-93.

61 Liu X, Grishanin RN, Tolwani RJ, Rentería RC, Xu B, Reichardt LF, et al. Brain-derived neurotrophic factor and TrkB modulate visual experience-dependent refinement of neuronal pathways in retina. J Neurosci. 2007; 27(27):7256-67.

62 Domenici L, Origlia N, Falsini B, Cerri E, Barloscio D, Fabiani C, et al. Rescue of retinal function by BDNF in a mouse model of glaucoma. PLoS One. 2014;9(12):e115579.

$63 \mathrm{Xu}$ L, Zhang Z, Xie T, Zhang X, Dai T. Inhibition of BDNF-AS provides neuroprotection for retinal ganglion cells against ischemic injury. PLoS One. 2016;11(12):e0164941.

64 Machaalani R, Chen H. Brain derived neurotrophic factor (BDNF), its tyrosine kinase receptor B (TrkB) and nicotine. Neurotoxicology. 2018;65:186-95.

65 Bai Y, Xu J, Brahimi F, Zhuo Y, Sarunic MV, Saragovi HU. An agonistic TrkB mAb causes sustained TrkB activation, delays RGC death, and protects the retinal structure in optic nerve axotomy and in glaucoma. Invest $\mathrm{Oph}$ thalmol Vis Sci. 2010;51(9):4722-31.
66 Chitranshi N, Dheer Y, Mirzaei M, Wu Y, Salekdeh GH, Abbasi M, et al. Loss of Shp2 rescues $\mathrm{BDNF} / \mathrm{TrkB}$ signaling and contributes to improved retinal ganglion cell neuroprotection. Mol Ther. 2019;27(2):424-41.

67 Ribeiro DE, Müller HK, Elfving B, Eskelund A, Joca SR, Wegener G. Antidepressant-like effect induced by $\mathrm{P} 2 \mathrm{X} 7$ receptor blockade in FSL rats is associated with BDNF signalling activation. J Psychopharmacol. 2019;33(11): 1436-46.

68 Perígolo-Vicente R, Ritt K, Gonçalves-de-Albuquerque $\mathrm{CF}$, Castro-Faria-Neto HC, Paesde-Carvalho R, Giestal-de-Araujo E. IL-6, A1 and A2aR: a crosstalk that modulates BDNF and induces neuroprotection. Biochem Biophys Res Commun. 2014;449(4):477-82.

69 Chen JF. Adenosine receptor control of $\operatorname{cog}$ nition in normal and disease. Int Rev Neurobiol. 2014;119:257-307.

70 Frank L, Ventimiglia R, Anderson K, Lindsay RM, Rudge JS. BDNF down-regulates neurotrophin responsiveness, TrkB protein and TrkB mRNA levels in cultured rat hippocampal neurons. Eur J Neurosci. 1996;8(6):122030.

71 Knusel B, Gao H, Okazaki T, Yoshida T, Mori $\mathrm{N}$, Hefti $\mathrm{F}$, et al. Ligand-induced down-regulation of Trk messenger RNA, protein and tyrosine phosphorylation in rat cortical neurons. Neuroscience. 1997;78(3):851-62.

72 Sommerfeld MT, Schweigreiter R, Barde YA, Hoppe E. Down-regulation of the neurotrophin receptor TrkB following ligand binding. Evidence for an involvement of the proteasome and differential regulation of TrkA and TrkB. J Biol Chem. 2000;275(12):898290.

73 Osborne A, Khatib TZ, Songra L, Barber AC, Hall K, Kong GYX, et al. Neuroprotection of retinal ganglion cells by a novel gene therapy construct that achieves sustained enhancement of brain-derived neurotrophic factor/ tropomyosin-related kinase receptor-B signaling. Cell Death Dis. 2018;9(10):1007.

74 Vempati P, Popel AS, Mac Gabhann F. Extracellular regulation of VEGF: isoforms, proteolysis, and vascular patterning. Cytokine Growth Factor Rev. 2014;25(1):1-19.

75 Penn JS, Madan A, Caldwell RB, Bartoli M, Caldwell RW, Hartnett ME. Vascular endothelial growth factor in eye disease. Prog Retin Eye Res. 2008;27(4):331-71.

76 Ashina K, Tsubosaka Y, Kobayashi K, Omori K, Murata T. VEGF-induced blood flow increase causes vascular hyper-permeability in vivo. Biochem Biophys Res Commun. 2015; 464(2):590-5.

77 Foxton RH, Finkelstein A, Vijay S, Dahlmann-Noor A, Khaw PT, Morgan JE, et al. VEGF-A is necessary and sufficient for retinal neuroprotection in models of experimental glaucoma. Am J Pathol. 2013;182(4):1379-90.
78 Beazley-Long N, Hua J, Jehle T, Hulse RP, Dersch R, Lehrling C, et al. VEGF-A165b is an endogenous neuroprotective splice isoform of vascular endothelial growth factor A in vivo and in vitro. Am J Pathol. 2013;183(3):91829.

79 Shen J, Xiao R, Bair J, Wang F, Vandenberghe LH, Dartt D, et al. Novel engineered, membrane-localized variants of vascular endothelial growth factor (VEGF) protect retinal ganglion cells: a proof-of-concept study. Cell Death Dis. 2018;9(10):1018.

80 Song Y, Song Q, Li L, Xu J, Liu X. Effect of ranibizumab on levels of IL-6 and VEGF in peripheral blood and aqueous humor of glaucoma rat model and association of IL-6 and VEGF with optic nerve damage. Exp Ther Med. 2018;16(3):2506-10.

81 Pang IH, Zeng H, Fleenor DL, Clark AF. Pigment epithelium-derived factor protects retinal ganglion cells. BMC Neurosci. 2007;8:11.

82 Zhou X, Li F, Kong L, Chodosh J, Cao W. Anti-inflammatory effect of pigment epithelium-derived factor in DBA/2J mice. Mol Vis. 2009; 15:438-50.

83 Vigneswara V, Berry M, Logan A, Ahmed Z. Pigment epithelium-derived factor is retinal ganglion cell neuroprotective and axogenic after optic nerve crush injury. Invest Ophthalmol Vis Sci. 2013;54(4):2624-33.

84 Unterlauft JD, Eichler W, Kuhne K, Yang XM, Yafai Y, Wiedemann P, et al. Pigment epithelium-derived factor released by Müller glial cells exerts neuroprotective effects on retinal ganglion cells. Neurochem Res. 2012; 37(7):1524-33.

85 Unterlauft JD, Claudepierre T, Schmidt M, Müller K, Yafai Y, Wiedemann P, et al. Enhanced survival of retinal ganglion cells is mediated by Müller glial cell-derived PEDF. Exp Eye Res. 2014;127:206-14.

86 Vigneswara V, Ahmed Z. Pigment epithelium-derived factor mediates retinal ganglion cell neuroprotection by suppression of caspase-2. Cell Death Dis. 2019;10(2):102

87 Wang X, Liu X, Ren Y, Liu Y, Han S, Zhao J, et al. PEDF protects human retinal pigment epithelial cells against oxidative stress via upregulation of UCP2 expression. Mol Med Rep. 2019;19(1):59-74.

88 Tian SW, Ren Y, Pei JZ, Ren BC, He Y. Pigment epithelium-derived factor protects retinal ganglion cells from hypoxia-induced apoptosis by preventing mitochondrial dysfunction. Int J Ophthalmol. 2017;10(7):104654 .

89 Eichler W, Savković-Cvijić H, Bürger S, Beck M, Schmidt M, Wiedemann P, et al. Müller cell-derived PEDF mediates neuroprotection via STAT3 activation. Cell Physiol Biochem. 2017;44(4):1411-24.

90 Lee SJ, Duncan DS, Echevarria FD, McLaughlin WM, Hatcher JB, Sappington RM. Pressure-induced alterations in PEDF and PEDF$\mathrm{R}$ expression: implications for neuroprotective signaling in glaucoma. J Clin Exp Ophthalmol. 2015;6(5):491. 
91 Vigneswara V, Esmaeili M, Deer L, Berry M, Logan A, Ahmed Z. Eye drop delivery of pigment epithelium-derived factor-34 promotes retinal ganglion cell neuroprotection and axon regeneration. Mol Cell Neurosci. 2015;68:212-21.

92 Miyazaki M, Ikeda Y, Yonemitsu Y, Goto Y, Murakami Y, Yoshida N, et al. Pigment epithelium-derived factor gene therapy targeting retinal ganglion cell injuries: neuroprotection against loss of function in two animal models. Hum Gene Ther. 2011;22(5):55965.

93 Fielder GC, Yang TW, Razdan M, Li Y, Lu J, Perry JK, et al. The GDNF family: a role in cancer? Neoplasia. 2018;20(1):99-117.

94 Ibáñez CF, Andressoo JO. Biology of GDNF and its receptors: relevance for disorders of the central nervous system. Neurobiol Dis. 2017;97(Pt B):80-9.

95 Hauck SM, Kinkl N, Deeg CA, Swiatek-de Lange M, Schöffmann S, Ueffing M. GDNF family ligands trigger indirect neuroprotective signaling in retinal glial cells. Mol Cell Biol. 2006;26(7):2746-57.

96 Omodaka K, Kurimoto T, Nakamura O, Sato K, Yasuda M, Tanaka Y, et al. Artemin augments survival and axon regeneration in axotomized retinal ganglion cells. J Neurosci Res. 2014;92(12):1637-46.

97 Koeberle PD, Bähr M. The upregulation of GLAST-1 is an indirect antiapoptotic mechanism of GDNF and neurturin in the adult CNS. Cell Death Differ. 2008;15(3):471-83.

98 Ward MS, Khoobehi A, Lavik EB, Langer R, Young MJ. Neuroprotection of retinal ganglion cells in DBA/2J mice with GDNF-loaded biodegradable microspheres. J Pharm Sci. 2007;96(3):558-68.

99 Jiang C, Moore MJ, Zhang X, Klassen H, Langer R, Young M. Intravitreal injections of GDNF-loaded biodegradable microspheres are neuroprotective in a rat model of glaucoma. Mol Vis. 2007;13:1783-92.

100 Checa-Casalengua P, Jiang C, Bravo-Osuna I, Tucker BA, Molina-Martínez IT, Young $\mathrm{MJ}$, et al. Retinal ganglion cells survival in a glaucoma model by GDNF/Vit E PLGA microspheres prepared according to a novel microencapsulation procedure. J Control Release. 2011;156(1):92-100.

101 Ohlmann A, Tamm ER. Norrin: molecular and functional properties of an angiogenic and neuroprotective growth factor. Prog Retin Eye Res. 2012;31(3):243-57.

102 Lee H, Jo DH, Kim JH, Kim JH. Norrin expression in endothelial cells in the developing mouse retina. Acta Histochem. 2013; 115(5):447-51.

103 Seitz R, Hackl S, Seibuchner T, Tamm ER, Ohlmann A. Norrin mediates neuroprotective effects on retinal ganglion cells via activation of the $\mathrm{Wnt} / \mathrm{beta}$-catenin signaling pathway and the induction of neuroprotective growth factors in Muller cells. J Neurosci. 2010;30(17):5998-6010.
104 Li HJ, Sun ZL, Pan YB, Sun YY, Xu MH, Feng DF. Inhibition of miRNA-21 promotes retinal ganglion cell survival and visual function by modulating Müller cell gliosis after optic nerve crush. Exp Cell Res. 2019;375(2): 10-9.

105 Kassumeh S, Leopold S, Fuchshofer R, Thomas CN, Priglinger SG, Tamm ER, et al. Norrin protects retinal ganglion cells from excitotoxic damage via the induction of leukemia inhibitory factor. Cells. 2020;9(2): 277.

106 Lin S, Cheng M, Dailey W, Drenser K, Chintala S. Norrin attenuates protease-mediated death of transformed retinal ganglion cells. Mol Vis. 2009; 15:26-37.

107 Leopold SA, Zeilbeck LF, Weber G, Seitz R, Bösl MR, Jägle $H$, et al. Norrin protects optic nerve axons from degeneration in a mouse model of glaucoma. Sci Rep. 2017;7(1): 14274

108 Dailey WA, Drenser KA, Wong SC, Cheng $\mathrm{M}$, Vercellone J, Roumayah KK, et al. Norrin treatment improves ganglion cell survival in an oxygen-induced retinopathy model of retinal ischemia. Exp Eye Res. 2017;164: 129-38.

109 Zhang K, Hopkins JJ, Heier JS, Birch DG, Halperin LS, Albini TA, et al. Ciliary neurotrophic factor delivered by encapsulated cell intraocular implants for treatment of geographic atrophy in age-related macular degeneration. Proc Natl Acad Sci U S A. 2011; 108(15):6241-5

110 Kauper K, McGovern C, Sherman S, Heatherton P, Rapoza R, Stabila P, et al. Two-year intraocular delivery of ciliary neurotrophic factor by encapsulated cell technology implants in patients with chronic retinal degenerative diseases. Invest Ophthalmol Vis Sci. 2012;53(12):7484-91.

111 Chew EY, Clemons TE, Peto T, Sallo FB, Ingerman A, Tao W, et al. Ciliary neurotrophic factor for macular telangiectasia type 2 : results from a phase 1 safety trial. Am J Ophthalmol. 2015;159(4):659-66.e1.

112 Birch DG, Weleber RG, Duncan JL, Jaffe GJ, Tao W. Randomized trial of ciliary neurotrophic factor delivered by encapsulated cell intraocular implants for retinitis pigmentosa. Am J Ophthalmol. 2013;156(2):283-92. el.

113 Chew EY, Clemons TE, Jaffe GJ, Johnson CA, Farsiu S, Lad EM, et al. Effect of ciliary neurotrophic factor on retinal neurodegeneration in patients with macular telangiectasia type 2: a randomized clinical trial. Ophthalmology. 2019;126(4):540-9.

114 Khodabande A, Roohipoor R, Zamani J, Mirghorbani M, Zolfaghari H, Karami S, et al. Management of idiopathic macular telangiectasia type 2. Ophthalmol Ther. 2019; 8(2):155-75.

115 Ferrari MP, Mantelli F, Sacchetti M, Antonangeli MI, Cattani F, D'Anniballe G, et al. Safety and pharmacokinetics of escalating doses of human recombinant nerve growth factor eye drops in a double-masked, randomized clinical trial. BioDrugs. 2014;28(3): 275-83.

116 Versura P, Giannaccare G, Pellegrini M, Sebastiani S, Campos EC. Neurotrophic keratitis: current challenges and future prospects. Eye Brain. 2018;10:37-45.

117 Bonini S, Lambiase A, Rama P, Sinigaglia F, Allegretti M, Chao W, et al. Phase II randomized, double-masked, vehicle-controlled trial of recombinant human nerve growth factor for neurotrophic keratitis. Ophthalmology. 2018;125(9):1332-43.

118 Dugel PU, Boyer DS, Antoszyk AN, Steinle NC, Varenhorst MP, Pearlman JA, et al. Phase 1 study of OPT-302 inhibition of vascular endothelial growth factors $\mathrm{C}$ and $\mathrm{D}$ for neovascular age-related macular degeneration. Ophthalmol Retina. 2020;4(3):250-63.

119 Jackson TL, Boyer D, Brown DM, Chaudhry N, Elman M, Liang C, et al. Oral tyrosine kinase inhibitor for neovascular age-related macular degeneration: a phase 1 dose-escalation study. JAMA Ophthalmol. 2017; 135(7):761-7.

120 Jaffe GJ, Ciulla TA, Ciardella AP, Devin F, Dugel PU, Eandi CM, et al. Dual antagonism of PDGF and VEGF in neovascular age-related macular degeneration: a phase IIb, multicenter, randomized controlled trial. Ophthalmology. 2017;124(2):224-34.

121 Csaky KG, Dugel PU, Pierce AJ, Fries MA, Kelly DS, Danis RP, et al. Clinical evaluation of pazopanib eye drops versus ranibizumab intravitreal injections in subjects with neovascular age-related macular degeneration. Ophthalmology. 2015;122(3):579-88.

122 Gandolfi S, Marchini G, Caporossi A, Scuderi G, Tomasso L, Brunoro A. Cytidine $5^{\prime}$-diphosphocholine (citicoline): evidence for a neuroprotective role in glaucoma. Nutrients. 2020;12(3):793.

123 Morishita S, Oku H, Horie T, Tonari M, Kida T, Okubo A, et al. Systemic simvastatin rescues retinal ganglion cells from optic nerve injury possibly through suppression of astroglial NF- $\kappa B$ activation. PLoS One. 2014; 9(1):e84387.

124 Zhang Y, Zhang Z, Yan H. Simvastatin inhibits ischemia/reperfusion injury-induced apoptosis of retinal cells via downregulation of the tumor necrosis factor- $\alpha /$ nuclear factor- $\mathrm{kB}$ pathway. Int J Mol Med. 2015; 36(2):399-405.

125 Ju WK, Shim MS, Kim KY, Bu JH, Park TL, Ahn $\mathrm{S}$, et al. Ubiquinol promotes retinal ganglion cell survival and blocks the apoptotic pathway in ischemic retinal degeneration. Biochem Biophys Res Commun. 2018; 503(4):2639-45.

126 Ekicier Acar S, Sarıcaoğlu MS, Colak A, Aktaş Z, Sepici Dinçel A. Neuroprotective effects of topical coenzyme Q10 + vitamin E in mechanic optic nerve injury model. Eur J Ophthalmol. 2020;30(4):714-22. 